\title{
The turn to authority beyond states ${ }^{*}$
}

\author{
Abstract \\ The concept of authority has become increasingly palatable to scholars in law, political science and \\ philosophy when describing, explaining and assessing global governance. While many now seem to \\ agree that applying authority to transnational relations opens fruitful arenas for legal, empirical and \\ normative research, they rely on partly incompatible notions of authority, how it emerges out of and \\ affects the social relations between key actors, and how it relates to legitimacy. In this paper, we \\ introduce this special issue on transnational authority. We discuss why international authority has \\ become a central concern in international studies and compare key contemporary conceptions of \\ international authority, highlighting their strengths and weaknesses. We also present the different \\ contributions to this issue, which further seek to clarify the concept and its application in law, \\ political science, and political theory, theoretically or empirically, assessing arenas where authority is \\ or is not legitimately exercised and developing legal conceptions, which might be utilized to constrain \\ the use of authority in international relations.
}

\footnotetext{
${ }^{*}$ Birgit Peters, PhD, post-doctoral researcher, University of Münster; Johan Karlsson Schaffer, PhD, senior researcher, University of Oslo. The papers in this special issue emanate from the 'Authority beyond states' project, which arranged a series of workshops in 2011 and 2012. As co-conveners of these workshops, we are grateful for financial support from the German Academic Exchange Service, the Research Council of Norway, the research project 'Should states ratify human rights conventions?', as well as the Faculty of Law and the Norwegian Centre for Human Rights at the University of Oslo. We also wish to thank the Centre franco-norvégien en sciences sociales et humaines in Paris for hosting the third workshop on 4-5 May, 2012, and professor Armin von Bogdandy, who delivered the keynote at the Paris workshop and kindly hosted the fourth workshop at the Max Planck Institute for Comparative Public Law and International Law, Heidelberg, Germany, 8-9 November 2012. We are also grateful to Ian Hurd for comments on this introduction. Last but not least, we thank the authors who contributed to this issue, the expert referees who volunteered to review the articles, and Peer Zumbansen and the editorship of TLT.
} 


\section{Transnational authority as a new field of study}

In recent years, scholars of international affairs have increasingly employed the concept of authority in order to address new phenomena in the global order. The debate on international authority has drawn the disciplines of politics, law and philosophy a little closer to each other. In international relations, the concept of authority has prompted scholars to question the fundamental assumption about anarchy as the ordering principle of the international system. In international law, exploring authority in global governance has allowed scholars to pose questions not only about the sources of international law, but also about the institutions and actors involved in its creation. And in political philosophy, the significance of authoritative institutions beyond the state has been a crucial bone of contention in recent debates about global justice and democracy.

This special issue starts from the assumption that it is now time to move these debates ahead by interconnecting them. Today, we hardly need to make the case that the concepts of authority and legitimacy are relevant for studying the processes and institutions of global governance, but for all the talk about authority across these disciplines, we lack a common conceptual toolbox or translation engine. The study of authority beyond states has followed different trajectories in different disciplines, and only recently do we see genuine attempts at engagement across disciplinary divides. This special issue contributes to that project. Certainly, we do not aim to present a comprehensive theory of authority; rather we wish to demonstrate how different conceptual apparatuses provide opportunities and constraints for analysing the myriad phenomena of global governance, thus advancing the transdisciplinary debate on authority beyond states.

Hence, this introduction serves three purposes: First, we discuss why international authority has recently become a central concern across the disciplines that study international affairs. Second, we introduce as we go along the contributions to this special issue, which reflect on the notion and the concept of authority and thus enlighten debates on its normative content and underlying premises, and/or consequences of and difficulties connected with its application in global governance. Third, we relate these contributions to key contemporary conceptions of international authority, and discuss their strengths and weaknesses. 


\section{Why turn to authority?}

The concept of international authority links current debates in legal, empirical and normative international studies. It is a key reference point in debates about sovereignty, about the normative force and development of international rules, about the rise of non-state actors in transnational legal and political processes, about the legitimacy of international institutions and the use of power and coercion in inter-state relations, to name but a few instances where authority is referenced.

Yet, until recently, international law and international relations debated the concept in distinct, but related ways. International legal scholars traditionally raised questions about the law's authority when discussing the normative force of international rules, or their creation, a debate which mostly centred on the law and its sources. ${ }^{1}$ It was concerned with the changing interpretations of international law, or its development over time, ${ }^{2}$ yet without addressing the corresponding right to rule of the international and transnational institutions involved in these law-making processes. More recently, however, debates about global governance, the growing influence of judicial networks, transnational law and global administrative law have turned international legal scholarship away from sources toward institutions, actors, interactions and processes. ${ }^{3}$ Reconsidering the concept of authority has thus initiated new, fruitful research agendas, demonstrating, for instance, how focusing on international public authority would render the broad phenomena of global governance more available to legal analysis. The concept of authority now allows, for example, evaluations of the impact of decisions of international institutions like the OECD's PISA study, which previously fell off the roster of international law analysis due to their 'soft-law' and non-binding character.

\footnotetext{
${ }^{1}$ Gerald G Fitzmaurice, 'The Foundations of the Authority of International Law and the Problem of Enforcement' (1956) 19 The Modern Law Review 1-13

${ }^{2}$ International Law Commission, 'Report of the Sixty-Fourth Session', 2012

${ }^{3}$ Armin von Bogdandy, Philipp Dann, and Matthias Goldmann, 'Developing the Publicness of Public International Law: Towards a Legal Framework for Global Governance Activities' in Armin von Bogdandy and others (eds), The Exercise of Public Authority by International Institutions, vol. 210 (Springer Berlin Heidelberg 2010), Beiträge zum ausländischen öffentlichen Recht und Völkerrecht
} 
In international relations, researchers have opened innovative fields of research by rethinking hierarchy/anarchy as the constitutive distinction between domestic and international politics.

Traditionally, mainstream theoretical approaches to international relations have shared the assumption that anarchy, defined as the absence of authority and hierarchy, is the distinctive ordering principle of the international system. A predominant formalist view of authority, whereby the authority of an international organization is simply the tasks states have delegated to it by ratifying its founding treaty, ruled out the possibility of international authority over states. ${ }^{4}$ For some time already, certain theorists have been calling for relaxing the paradigmatic basic assumptions about what distinguishes domestic and international politics. ${ }^{5}$ Yet only recently have such calls translated into more systematic theoretical engagements with the concept of authority and rigorous empirical tests, studying, for instance, how regional hegemons, international organizations like the UN Security Council, private regulators, or international judicial institutions exercise authority, and how their various subjects react.

And in political philosophy, a contentious issue in recent debates about cosmopolitanism and global justice concern whether the world order today represents a 'global basic structure', i.e., a shared, authoritative institutional framework with a direct impact on people's life chances, and whether such a framework is necessary for concepts like justice, morality or democracy to apply beyond the confines of nation states. Cosmopolitans disagree about why principles of justice have global scope: Some argue that since we all participate in a global basic structure, principles of justice that apply domestically should apply globally as well, while others claim that empirical premises about the extent or depth of global order are irrelevant for the content, scope and justification of principles of justice, and therefore, such principles must have global scope. ${ }^{6}$ Either way, the nature of authority in the international arena turns out to be crucial.

\footnotetext{
${ }^{4}$ Ian Hurd, 'Theories and tests of international authority' in Bruce Cronin and Ian Hurd (eds), The UN Security Council and the Politics of International Authority (1st edn, Routledge 2008) 27f; David A. Lake, 'Escape from the State of Nature: Authority and Hierarchy in World Politics' (2007) 32 International Security 47, 62

${ }^{5}$ Helen V. Milner, 'Rationalizing Politics: The Emerging Synthesis of International, American, and Comparative Politics' (1998) 52 International Organization 758-786

${ }^{6}$ Michael Blake, 'Global Distributive Justice: Why Political Philosophy Needs Political Science' (2012) 15 Annual Review of Political Science 121-136; Thomas Nagel, 'The Problem of Global
} 
To complicate things, this turn to authority represents both claims that there has been an empirical shift, with ever more institutions and actors, public and private, expanding their claims to authority over states and other subjects, and a theoretical shift, where adding 'international authority' to the conceptual toolbox available to researchers allows them to see and describe the empirical shift, or dispute such claims. As Henrik Enroth describes in his essay for this issue, re-conceptualising global governance in terms of authority (rather than in terms of its absence), has allowed us to think of the global as a domain of rule in its own right. Since the two shifts are interrelated, it often turns out to be difficult to test propositions about authority. In particular, while many scholars now seem to agree that applying authority to transnational relations opens fruitful arenas for legal, empirical and normative research, they rely on partly incompatible notions of authority, how it emerges out of and affects the social relations between key actors, and how it relates to legitimacy.

This special issue includes five articles that take on this challenge. The first three contributions explore in particular, the concept's relations to established notions of sovereignty, coercion, consensus or autonomy, and illustrate specific notions of authority for the study of transnational and global governance relations. Other contributions then assess investigate spaces traditionally perceived to lack legitimate authority; or suggest legal principles, which help to analyse authority in multi-levelled governance contexts.

In the first article, Henrik Enroth analyses how the concept of authority was appropriated to redescribe global governance, which was originally conceived in the 1990s as characterised as governance in the absence of authority. Intriguingly, Enroth argues, what changed through this recontextualisation was not the meaning of authority, which preserved its ambiguity and openness, but the way we think about the global, with its myriad actors and institutions, as a domain of rule proper. Projecting the concept of authority to the transnational sphere allows us to think and act as if we were still subjects in the equivocal sense of democratic citizenship, being both authors and addressees of the authoritative norms that govern us. However, Enroth also warns that the temptation to redescribe 
global governance in terms of authority - with all its ambiguous normative baggage - may also make it more difficult to speak truth to global power.

The contribution by Ingo Venzke then offers a theoretical understanding of authority, and more particularly of the authority of international institutions to make law. In developing his account of authority, which is generated through communicative action and supported by past practices, Venzke addresses previous suggestions on authority as advanced by Arendt, Weber, Raz and Habermas and elucidates how international institutional authority needs to be distinguished from the notions of both power and persuasion. Thus construed, Venzke argues, international authority traditionally arises out of moments of consent and is thus different from the exercise of power. At the same time, authority needs to constrain even in the absence of agreement in substance and is thus different from persuasion. International institutions' authority in making law, Venzke argues, is best understood as their capacity to establish contentful reference points for legal discourse. In the ultimate analysis, this capacity is sustained by the expectations of the larger discursive community..

Patrick Smith argues that debates on transnational authority often confuse two distinct approaches to of authority. On the instrumental view - eminently exemplified by Joseph Raz authoritative political institutions are justified in terms of helping people realize pre-politically defined moral objectives they otherwise could not obtain. On the constitutive view, by contrast, legitimate political institutions are not justified as means to certain moral ends; rather, a just political order partly constitutes what it means for human beings to live in freedom. While the instrumentalist notion of authority seemingly fits the image of contemporary global governance, Smith argues, it fails to justify political institutions where a right to rule includes a right to coerce non-compliers. To the extent that transnational institutions exercise authority, Smith concludes, it must chiefly be of the instrumentalist variety, as they must ultimately rely on the coercive power of states in order to ensure compliance with their directives.

The last two contributions look at authority in the special context of international judicial institutions. The paper by Michal Onderco, Barbora Hola and Stijn Ruiter addresses a crucial issue in the theory of international authority: Do international institutions exercise independent and impartial authority, or are they chiefly agents serving the interests of their principals, that is, states? Most 
theoretical conceptions of international authority would expect international institutions, to the extent that they exercise authority, to be detached from the states that have created them by delegating certain powers. Independence, impartiality and even-handedness is an especially important feature of legitimacy of international judicial institutions, such as international criminal tribunals. Onderco, Hola \& Ruiter seek to test whether international criminal judges on the International Criminal Tribunal for former Yugoslavia (ICTY) act independently in their sentencing decisions or are subject to political constraints. Their findings indicate that the exercise of judicial authority at the ICTY is indeed independent whereas political factors, such as the geopolitical orientation of the state nominating judges, play no significant role - which is, certainly, good news for anyone concerned with the legitimate authority of the international criminal law system.

Simon Hentrei, finally, addresses the principle of complementarity. He argues that legitimacy concerns, which ensue over the increased exercise of authority by international courts on individuals and states, might be mitigated by the application of a generalised principle of complementarity. Complementarity may condition the relationship between national and international courts thus safeguarding individual freedom and collective self-determination. In contrast to other principles, which have been advanced to address this relationship, such as the principle of subsidiarity, Hentrei argues that complementarity offers a more precise research basis. Subsidiarity, by contrast, does not offer a uniform approach since it is applied differently in differing contexts and builds on hierarchical relationships between international actors. As one of several features of the principle, Hentrei names the local remedies rule, which can be found as a procedural requirement to access international courts. The margin of appreciation doctrine could be identified as one substantive element of the principle.

\section{Conceptions of transnational authority}

Taken together, the contributions to this issue aim to illustrate strengths and weaknesses of competing conceptions of transnational and international authority as a new tool for analysing new phenomena in global governance and international relations, and hope to shed light on some of the existing debates on authority and its uses in international legal and political theory. As a conceptual background to the individual contributions, we now consider five influential conceptions of authority and illustrate 
selected theoretical implications, which all highlight key controversies in recent debates about transnational authority. In turn, we discuss Joseph Raz's "service conception” of authority; the international public law approach to authority of Armin von Bogdandy et al; Ian Hurd's constructivist account of authority as internalized normative beliefs; David Lake's social contract theory of international hierarchy; and Michael Zürn's et al account of how international authority provokes politicization. Their differences reflect how different authors approach the topic of international authority with different agendas and research problems in mind, and as a result their conceptions of authority differ along at least four crucial dimensions. The individual contributions to this special issue all explore further dimensions of conceptual diversity and theoretical richness.

The first controversy concerns the origins of authority: How can an institution come to hold authority over those who created it by consent? Scholars agree that authority needs to be distinguished from delegated competence, vested into an institution by virtue of its founding document, yet disagree about where authority comes from. Some draw on social contract theory and thus on consent, similar to the standard voluntarist approach to international law. However, contractual conceptions have difficulties making sense of how international institutions sometimes expand their competences beyond what states originally consented to. This view also invites classical objections against contractarianism. ${ }^{7}$ Still, even in today's transnational relations, state consent plays a major role in legitimating new forms of global governance. ${ }^{8}$

Second, a key issue of contention concerns whether authority conceptually implies legitimacy. The tautological view that defines authority as 'legitimate rule' is dominant, and represented here by Raz, Hurd and Lake, but there may be analytical advantages in disentangling the concepts. As indicated by von Bogdandy et al and Zürn et al, refining this distinction suggests interesting prospects

\footnotetext{
${ }^{7}$ David Hume, 'Of the original contract' in Essays, Moral, Political, and Literary (Liberty Fund 1987)

${ }^{8}$ Duncan B. Hollis, 'Why state consent still matters: Non-state actors, treaties, and the changing sources of international law' (2005) 23 Berkeley Journal of International Law 1-39
} 
for studying cases where the authority exercised by actors of global governance conflict with the demands of legitimacy. ${ }^{9}$

Third, scholars disagree about how authority relates to the concept of power as expressed through other modes of interaction. This problem involves a dilemma. If one stringently defines authority in contradistinction to coercion, self-interest and reasoning, one risks making legitimacy empirically implausible. Conversely, if one regards authority as resulting from self-interested consent and backed up by coercion, the trade-off is a difficulty to tell authority apart from illegitimate transnational interactions.

Fourth, an issue which similarly affects empirical assessments of the extent of transnational authority is the relation between authority and bindingness. Stricter views, where authority implies a hierarchical relation, obligating subjects to obey, would exclude many forms of transnational governance exercised by, for instance, private regulators, international treaty bodies or technocratic agencies - whatever their influence, it is not a form of authority. By contrast, to include both binding and non-binding acts opens for assessing, for example, country rankings as a form of authoritative determination that influences freedom, but also invites objections that authority thereby becomes too broad a concept to be analytically useful.

The order, in which the approaches are presented follows both historical and disciplinary logics. We start with Raz's account of authority, originally formulated in the 1980 s, which several scholars have recently applied to international law and politics. We then continue with another prominent suggestion from law on the notion of authority, which is the public law approach developed by Bogdandy et al. Then follow Hurd and Lake, whose conceptions of authority represent contrasting approaches to international theory. We conclude our discussion with the recent suggestion of Zürn et al. who are responding to the earlier suggestions both from law and political science.

\footnotetext{
9 Jonathan G. S. Koppell, 'Global Governance Organizations: Legitimacy and Authority in Conflict' (2008) 18 Journal of Public Administration Research and Theory 177-203
} 
Authority in practical reasoning - Raz

A highly influential account in the theory of authority is Joseph Raz's so-called service conception of authority. As an account of practical reasoning, the service conception proposes for what reason an authority may be perceived as legitimate. It applies to all authorities that claim to exercise legitimate authority: political, governmental, legal, and de facto. ${ }^{10}$ Raz argues that reasons for a right to rule - of the law, political authorities, governments, or other institutions - need to comply with three conditions. First, they need to be based on independent reasons which are relevant to the subjects in the circumstances regulated by the directive (dependency thesis). ${ }^{11}$ Second, if accepted as binding, they need to provide better reasons for action than those, which would apply to the actor anyway (normal justification thesis). ${ }^{12}$ Third, they need to be pre-emptive, i.e. they ought not to be added to other relevant reasons for compliance, but exclude other reasons and take their place. ${ }^{13}$ As mentioned, for Raz, authority is indistinguishable from legitimacy, for, on his view, only the authority with legitimate effective authority provides acceptable, moral reasons for action for another actor. ${ }^{14}$ Directives that do not comply with the service conception need not to be followed. According to Raz, political authorities, in particular, fulfil the three requirements of the service conception in a variety of cases, and in our context of transnational and international institutional authority the most relevant would probably be that (1) they offer epistemic expertise; (2) they solve coordination problems; and (3) they provide first order reasons for following the law. ${ }^{15}$ But this is neither an accumulative nor an exhaustive list of characterisations of legitimate rule; yet it covers a variety of situations in which the

\footnotetext{
${ }^{10}$ Joseph Raz, 'The Problem of Authority: Revisiting the Service Conception' (2006) 90 Minnesota Law Review 1003-1044

${ }^{11}$ Joseph Raz, 'Authority, law and morality' (1985) 68 The Monist 295, 299; Joseph Raz, The Morality of Freedom (Oxford University Press 1988) 42, 47

${ }^{12}$ Raz, 'The Problem of Authority' (n__) 1014; Raz, 'Authority, law and morality' (n__) 299

${ }^{13}$ Raz, The Morality of Freedom (n__) 47

${ }^{14}$ Joseph Raz, The authority of law: essays on law and morality (Reprinted. Oxford Univ. Press 2002)

7, 27; Raz, 'Authority, law and morality' (n _ ) 296

${ }^{15}$ Raz, The Morality of Freedom (
} 
authority of an entity might be challenged. ${ }^{16}$ In addition, governments, in particular, need to fulfil the requirements of the service conception of authority and must be able to use the moral right expressed in that conception effectively. ${ }^{17}$

Combining rational with moral elements, the Razian account of authority remains abstract - not least because Raz offers no further definitions of the (objective) moral elements, which form part of his account. ${ }^{18}$ Yet, his account of authority starts from the premises of the individual actor- or addressee of (institutional) authority and is therefore compelling. The concept of legitimacy, which is intrinsically connected with Raz' perception of authority, is concerned with the question why agents comply with certain rules, starting amongst others, from a view of the addressee of the directive. ${ }^{19}$

Drawing on a definition this general, the Razian concept has been picked up by many political and legal theorists concerned with questions of transnational and international authority. Approaches assessing transnational and international authority drawing on Raz range from traditional accounts of the authority of international or transnational law, to modern conceptions concerned with the authority and democratic legitimacy of international and transnational institutions. Samantha Besson offers a prominent example, which explores the juncture between the legal and institutional perspective on international authority. ${ }^{20}$ Besson adapts Raz's theory by emphasising the coordinative character of international law in the pluralistic world of international relations. Even though she is concerned with

\footnotetext{
${ }^{16}$ Raz, The Morality of Freedom ( $\mathrm{n}_{-}$)

${ }^{17}$ Raz, 'The Problem of Authority' (

${ }^{18}$ For a critique of the idea of objective moral reasons, see H. L. A Hart, Essays on Bentham: studies in jurisprudence and political theory (Clarendon Press; Oxford University Press 1982); but see also Michael S. Moore, 'Authority, Law, and Razian Reasons' (1988) 62 Southern California Law Review 827
}

${ }^{19}$ Thomas M. Franck, 'Legitimacy in the International System' (1988) 82 The American Journal of International Law 705, $705 \mathrm{f}$

${ }^{20}$ S. Besson, 'The Authority of International Law: Lifting the State Veil' (2009) 31 Sydney Law Review 343-380; Samantha Besson, 'The legitimate authority of international human rights: On the reciprocal legitimation of domestic and international human rights' in Andreas Føllesdal and others (eds), The legitimacy of international human rights regimes: Legal, philosophical and political perspectives (Cambridge University Press 2013) 
constructing an account of legitimate international law, ${ }^{21}$ Besson's reinterpretation of Raz still recognizes the importance and role of international and transnational institutions as subjects and objects of international legal authority and goes as far as stipulating that the coordination required to legitimize new international law must comply with democratic principles. ${ }^{22}$ The Razian service conception has especially drawn interest in the human rights area, where some seek to present general theories of the legitimacy of international human rights $\mathrm{law}^{23}$, the normative authority of international human rights bodies ${ }^{24}$, or the legitimate uses of the margin of appreciation and dynamic interpretation doctrines by the European Court of Human Rights. ${ }^{25}$

Still, it is doubtful whether Raz provides a useful account for assessing the exercise of authority by international and transnational institutions. Most generally, on account of the plurality and heterogeneity of possible addressees of international norms and directives, one may question whether the Razian approach can generally identify whether or not a certain directive issued by an international or transnational institution is legitimate, since all these addressees might rely on a variety of reasons for following the directive or not. Only by introducing qualifiers, such as Besson's coordination-based interpretation, would the conception generate such clarity. Yet, as Venzke argues (this issue), the Razian conception fails to grasp how authority may come in degrees rather than dichotomy, if it is conceived as a discursive practice which shifts the balance of argumentative burdens.

Moreover, the service conception is built on the assumption that authority is accepted as binding, a criterion which is particularly difficult to meet in current international relations, where neither the

\footnotetext{
${ }^{21}$ Besson, 'The Authority of International Law' (n _ $) 357$

${ }^{22}$ Ibid. $362 \mathrm{f}$

${ }^{23}$ Besson, 'The legitimate authority of international human rights' ( Rights, Legitimacy, and International Law' (2013) 58 The American Journal of Jurisprudence 1-25

${ }^{24}$ Steven Wheatley, 'On the legitimate authority of international human rights bodies' in Andreas Føllesdal and others (eds), The legitimacy of international human rights regimes: Legal, philosophical and political perspectives (Cambridge University Press 2013)

${ }^{25}$ Andrew Legg, The Margin of Appreciation in International Human Rights Law: Deference and Proportionality (Oxford University Press, USA 2012); George Letsas, 'The ECHR as A Living Instrument: its Meaning and its Legitimacy' in Geir Ulfstein and others (eds), The European Court of Human Rights in a National, European and Global Context (Cambridge University Press 2013)
} 
acceptance nor the bindingness of a decision are sine qua non identifiers for whether or not the decision-making institution has authority, or whether its decisions are followed or influential. Also, criteria like epistemic expertise or the solution of coordination problems are often perceived as necessary, but not sufficient criteria for the determination of the legitimacy of an international institution or actor. But, as Patrick Smith notes (this issue), merely because an agent is correct about what it commands, being correct does not thereby necessarily justify a right to coercively impose that judgment. And, as Allen Buchanan puts it, "whatever else having the right to rule entails, it surely includes being justified in attempting to rule.,"26

Moreover, studies on the legitimacy of global governance phenomena are often concerned with the procedures which ensue among the global governance actors or institutions. ${ }^{27}$ Accordingly, writers emphasise the importance of procedural aspects, like the transparency of decision-making procedures, or democratic participation in the institutions' decisions. ${ }^{28}$ Even though these criteria may be held to be captured by the normal justification thesis, ${ }^{29}$ because they provide content-independent reasons for action, this would essentially mean that the normal justification thesis would absorb any other legitimacy theory. ${ }^{30}$

Finally, and most importantly, Raz' service conception conflates the concepts of legitimacy and authority, even though he does not exclude that an institution or entity could exercise illegitimate authority. Yet, it may be useful to keep those concepts apart, especially when considering transnational or public international authority (an argument to which we return below). Recent discussions on, for example the sanctions directed against individuals by the UN Security Council, as well as on earlier issues, like the NATO campaign in Kosovo, suggest that the exercise of international

\footnotetext{
${ }^{26}$ Allen Buchanan, 'The legitimacy of international law' in The philosophy of international law (Oxford University Press 2010) 85

${ }^{27}$ Bogdandy, Dann, and Goldmann, 'Developing the Publicness of Public International Law' (n__ 7

${ }^{28}$ Scott Hershovitz, 'The Role of Authority' (2011) 11 1, 1, 4

${ }^{29}$ Raz, 'The Problem of Authority' (n _ _ $) 1031$

${ }^{30}$ Hershovitz, 'The Role of Authority' ( $\mathrm{n} \_$) 5
} 
authority may be legal but illegitimate. ${ }^{31}$ Theorizing or conceptualizing transnational or international authority must therefore allow for accounts concerned with its normative legitimation, as well as the consequences which ensue if authority falls short of complying with those criteria.

\section{International public authority - Bogdandy et al.}

The public law approach to international authority recently developed by Armin von Bogdandy and associates circumvents some problems of the Razian account. Bogdandy et al define international public authority as "any kind of governance activity by international institutions, be it administrative or intergovernmental", which determines subjects - individuals, private associations, enterprises, states, or other public institutions - and influences their freedom by unilaterally shaping their legal or factual situation. ${ }^{32}$

As many authors concerned with authority, Bogdandy et al seek to move beyond the concept of global governance, which they argue fails to single out the acts of governance relevant from a public law perspective, namely acts where unilateral authority is exercised. Starting from a liberal-democratic perspective, yet influenced by sociological institutionalism (compare the illustrations by Venzke, this issue), the authors build their concept on the tension concerned by public law: the tension between unilateral authority, individual freedom and public self-determination. ${ }^{33}$ On their view, an international public authority comes about when states (or other public authorities) create an international institution and endow it with competences to further a goal which they define as a public interest. While an international institution thus helps states achieve certain collective goods they cannot otherwise obtain, it also constrains the autonomy of both states and their citizens, which is why international authority needs to be legitimated towards its subject. ${ }^{34}$ Bogdandy's et al concept of

\footnotetext{
${ }^{31}$ Independent International Commission on Kosovo, The Kosovo Report: Conflict, International Response, Lessons Learned (Oxford University Press 2000)

${ }^{32}$ Bogdandy, Dann, and Goldmann, 'Developing the Publicness of Public International Law' (n__) 5

${ }^{33}$ Ibid. $12 \mathrm{f}$

${ }^{34}$ Cf. Johan Karlsson Schaffer, 'Legitimacy, human rights and global governance institutions: Inverting the puzzle' in Andreas Føllesdal and Geir Ulfstein (eds), The legitimacy of international human rights regimes: Legal, philosophical and political perspect (Cambridge University Press 2013)
} 
unilateral public authority also emphasises the autonomy of an international or transnational institution's decisions. Hence, neither the usual reliance on state consent, nor the account that international institutions preserve certain collective values, can provide an immediate legitimation for the institution's acts or decisions. Rather, Bogdandy et al contend, international and transnational institutions exercise a form of authority which requires external normative legitimation via a public law framework, ${ }^{35}$ thus separating the concepts authority and legitimacy.

Relying on an institution's capacity to “determine” others, Bogdandy's et al account of authority includes both binding acts, which modify the legal situation of a subject without its consent, and acts not formally binding, which only condition other subjects, for instance by changing the opportunity structures they face. Examples of such non-binding yet authoritative acts are OECD standards on double-taxation or the PISA rankings mentioned above, which can only be avoided at some costs, whether reputational or economic. ${ }^{36}$ Authority, on this view, rests on an assumption of publicness, which is perceived as the authority exercised on the basis of a competence instituted by a political collective, or to further a goal which they perceive of public interest, or for the protection of a global public good. ${ }^{37}$

The international public authority approach thus appears to circumvent two of the problems outlined above. Unlike the Razian account, Bogdandy et al do not conflate legitimacy and authority. Moreover, they avoid the problems involved in assuming that authority entails the acceptance of an international directive as binding: Formally non-binding acts of international institutions may be authoritative, too. Deliberately broad, this definition includes a wide range of governance activities as

${ }^{35}$ Armin von Bogdandy, 'General Principles of International Public Authority: Sketching a Research Field The Exercise of Public Authority by International Institutions' in Armin von Bogdandy and others (eds), , vol. 210 (Springer Berlin Heidelberg 2010), Beiträge zum ausländischen öffentlichen Recht und Völkerrecht; Armin von Bogdandy and Ingo Venzke, 'In Whose Name? An Investigation of International Courts' Public Authority and Its Democratic Justification' (2012) 23 European Journal of International Law 7, 8

${ }^{36}$ Bogdandy, Dann, and Goldmann, 'Developing the Publicness of Public International Law' ( 11; Armin von Bogdandy and Matthias Goldmann, 'The Exercise of International Public Authority through National Policy Assessment' (2008) 5 International Organizations Law Review 241, 265

${ }^{37}$ Bogdandy, Dann, and Goldmann, 'Developing the Publicness of Public International Law' ( 13; Bogdandy and Goldmann, 'The Exercise of International Public Authority through National Policy Assessment' ( 
instances of authority. Yet, the account is less clear with regard to the influence and impact of nonstate organisations or transnational actors, like the ISO Standard Association, or the ICANN, which, as privately incorporated associations, establish standards or regulations relevant for the public domain and receive recognition via their 'institutional embeddedness' at the global and/or the national level. ${ }^{38}$ Bogdandy et al contemplate that ICANN might exercise public authority, albeit not on a strict account. ${ }^{39}$ Nonetheless, their definition of publicness rests upon the establishment of institutional competence by a political collective, a requirement usually not fulfilled in case of privately incorporated transnational actors, or other instances of hybrid public-private governance. At any rate, this strict definition has the virtue of weeding out many of the more sweeping claims about transnational authority, which, as Enroth notes (this issue), may make the concept "look confusingly like plain power, with no de jure basis".

A related problem is the conceptual link between international public authority and individual freedom, as illustrated by Bogdandy's et al evolving definition of the concept. Originally, the approach conceives of authority as a legal capacity to "reduce" or "curtail" freedom, thus close to the classical conception of negative liberty. ${ }^{40}$ However, the impact of authority is usually complex: it produces both constraints and opportunities for those on the receiving end, and distributes them unevenly. Moreover, different types of international institutions have quite different effects on both states and individuals subject to their authority. ${ }^{41}$ More recently, Bogdandy \& Venzke conceptualize the determination involved in authority in terms of "influence" on freedom. ${ }^{42}$ This rephrasing might reflect, first, a more nuanced view on how authority affects freedom, and second, that the normative

\footnotetext{
${ }^{38}$ Olaf Dilling, 'From Compliance to Rulemaking: How Global Corporate Norms Emerge from Interplay with States and Stakeholders' (2012) 13 German Law Journal 381, 407f; Olaf Dilling, Martin Herberg, and Gerd Winter, 'Introduction: Exploring transnational administrative rule-making' in Olaf Dilling and others (eds), Transnational administrative rule-making: performance, legal effects, and legitimacy (Hart 2011)

${ }^{39}$ Bogdandy, Dann, and Goldmann, 'Developing the Publicness of Public International Law' (n _ )

${ }^{40}$ Ibid.; Bogdandy and Goldmann, 'The Exercise of International Public Authority through National Policy Assessment' (n__) 263

${ }^{41}$ Schaffer, 'Legitimacy, human rights and global governance institutions' (

${ }^{42}$ Bogdandy and Venzke, 'In Whose Name?' (n _ _)
} 
problem in international public authority is its unilateral - and thus possibly arbitrary - exercise, similar to how republican conceptions of liberty have shifted the focus from the traditional liberal concern with freedom from interference toward freedom from dominance. ${ }^{43}$ In this issue, Patrick Smith argues that transnational institutions may exercise authority in the instrumentalist sense of providing expertise and coordination, but they can hardly possess the type of enforcement authority that rests on the capacity to physically control bodies in space, which makes freedom under legitimate political institutions both necessary and possible. On this view, it is a crucial demand of legitimacy that power be exercised non-arbitrarily. Still, the international public authority approach's definition of authority as unilateral determination might deviate from the common view that for authority relationships to exist, subjects must have a degree of freedom to decide whether to comply or not. Sometimes, the subjects' latitude to act may result in disobedience or resistance (for contrasting ideas on both these aspects of authority, see both Lake and Zürn et al below).

\section{Ian Hurd - Authority as internalized norms}

Ian Hurd has elaborated a theory of international authority informed by constructivist approaches to international relations. A crucial aspect of his account of authority is whether agents internalize notions of legitimacy, and redefine their interests in terms of deferring to authority, which in turn influences their behaviour.

Approaching international political authority as a sociological concept, Hurd defines it as "a social relation where a hierarchical relation in the international sphere is recognized as legitimate." ${ }^{, 44}$ If legitimacy is the distinctive feature of authority, it needs to be conceptually differentiated from other types of power relations. For this purpose, Hurd contrasts legitimacy to two other generic reasons why social agents follow rules: Coercion and self-interest. As ideal-typical mechanisms of social control, all three may exist in various combinations in actual social systems. Coercion, firstly, refers to a relation of asymmetrical power which is used to change the behaviour of the weaker agent, where the

\footnotetext{
${ }^{43}$ Philip Pettit, 'Dahl's power and republican freedom' (2008) 1 Journal of Power 67-74

${ }^{44}$ Hurd, 'Theories and tests of international authority' ( $\ldots$ _ $) 26$
} 
mere fear of punishment produces acquiescence. ${ }^{45}$ Coercion is inefficient: Systems which rely chiefly on coercion expend enormous resources on enforcement and surveillance, and since they fail to encourage voluntary obedience among the subjects, they tend either to collapse or to develop more sophisticated, legitimated mechanisms of control. Self-interest, secondly, is distinct from coercion, in part because it involves more complex incentives than the avoidance of physical violence. On this view, individuals follow rules when doing so is in their own self-interest: They instrumentally calculate the net benefits of compliance versus non-compliance. Assuming that agents have an instrumental attitude toward social structures and other people, a system relying on self-interest would tend to be volatile and long-term relationships would be difficult to maintain, because actors do not value the relation itself.

Legitimacy, thirdly, implies that agents act out of an internal sense of moral obligation - they believe that a rule or an institution ought to be obeyed. Legitimacy, on this view, is both subjective as a property of an actor, and relational between the actor and the institution. When an actor reconceives his or her own interests according to external, societal standards (laws, rules, norms, etc), those standards may affect behaviour: "Compliance then becomes habitual, and it is noncompliance that requires of the individual special consideration and psychic costs. ${ }^{\circledR 46}$ Since internalization affects how agents view their own interests, on this view we cannot look for legitimacy in instances where an agent complies with a legitimate rule that contravenes its interests (such as costly signalling). ${ }^{47}$ Rather, legitimacy beliefs, once widely shared in society, change the decision environment for all actors, "even those who have not been socialized to the rule, because it affects everyone's expectations of the likely behaviour of other players. ${ }^{, 48}$ In the long run, legitimacy is more efficient than alternative

\footnotetext{
${ }^{45}$ Ian Hurd, 'Legitimacy and authority in international politics' (1999) 53 International Organization 379,383

${ }^{46}$ Ibid. 388

${ }^{47}$ Ian Hurd, After anarchy: Legitimacy and power in the United Nations Security Council (Princeton University Press 2007) 45

${ }^{48}$ Ibid. 7
} 
modes of social control, since it reduces certain types of enforcement and increases the subjects' freedom. ${ }^{49}$

Hurd's conception of authority and legitimacy is both theoretically sophisticated, drawing on sociological and legal theory and engaging constructivist and rationalist approaches to international relations, and empirically productive for generating testable propositions about the behaviour of agents. His typology provides some welcome conceptual clarity, as it manages to distinguish different logics that may be thought to govern relationships of power. However, how strictly should we, first, interpret his typology of reasons of action? Much of his argument seems to depend on regarding coercion, self-interest and legitimacy as mutually exclusive at a conceptual level. But can real-world rule-following be described exclusively in terms of one ideal-typical reason? For example, Hurd argues that international authority is exercised in hierarchical relationships. Yet, Hentrei's contribution to this issue exemplifies that the relations of international and domestic courts can hardly be perceived as hierarchical, due to the multiplicity of fora available to the individual claimant. Other conceptions of authority surveyed here do not separate authority so strictly from coercion or self-interest, or tie it so closely to legitimacy. Moreover, where governing bodies rely on compound repertoires of social control, the subjects of political authority may comply out of both internalised beliefs about legitimacy and a calculus of punishment and rewards. ${ }^{50}$

Second, conceiving of legitimacy as a subjective feeling, indicated by habitual rule-following, is problematic, even if we accept the controversial assumption that collective actors such as states are persons with feelings. ${ }^{51}$ Coercion and self-interest can both be reconstructed as rational motivations, that is, as beliefs that can be supported by reasons. By contrast, legitimacy, as Hurd describes it, operates mainly in an emotional register: It is a "subjective feeling" or "internal sense" (of moral

\footnotetext{
${ }^{49}$ Hurd, 'Legitimacy and authority in international politics' (n_ $) 388$

${ }^{50} \mathrm{cf}$. Johannes Gerschewski, 'The three pillars of stability: legitimation, repression, and co-optation in autocratic regimes' (2013) 20 Democratization 13-38

${ }^{51}$ For a defence, see Alexander Wendt, 'The state as a person in international theory' (2004) 30 Review of International Studies 289-316
} 
obligation) that alters an actor's behaviour. ${ }^{52}$ Now, if we understand legitimacy as an emotion or intuition, it seems to elude not only rational reconstruction but also behavioural observation.

Moreover, Hurd conforms to an influential view which regards authority as antithetical to reason: "the logic of the authority relation makes reasoning unnecessary, and perhaps even undermining. Authority involves the 'surrender of private judgment' so that the audience's critical faculties are irrelevant to the process.. ${ }^{, 3}$ Once an agent starts giving reasons for its compliance, it has left the domain of authority and reclaimed private judgment. But confining the concept to situations where agents act on emotions or habit, rather than on reflected reasons, seems to make authority empirically implausible in the political sphere. As Venzke (this issue) notes, public international institutions are often obligated to give reasons for their actions and decisions, and the government subject to their jurisdiction are pressured to explain their compliance - a fact which does not preclude that the institutions exercise authority, although such persuasion cannot be its only basis.

To address these issues, it seems fruitful to relax the presumption that authority precludes reasoning. Drawing on communicative action theory, Thomas Risse suggests arguing as a logic of social action distinct from both the instrumental calculation of costs and benefits, and behaviour guided by internalised rules. ${ }^{54}$ As an interactive learning process, through which agents come to internalise norms and revise how they perceive their own interests, arguing and deliberation suggest an essential mechanism of legitimation. If agents come to accept a rule or institution as authoritative through a process of reasoning, their subsequent reflection on and reactivation of those reasons need not indicate the absence of authority. Hurd seems to cede as much when indicates that we should not understand authority in a way that makes for subordinates who are automatons, who do not think strategically or reflexively about authority, and, furthermore, suggests using the justifications states

\footnotetext{
${ }^{52}$ Ian Hurd, 'Myths of Membership: The Politics of Legitimation in UN Security Council Reform' (2008) 14 Global Governance 199, 38; Hurd, After anarchy (n__) 33f

${ }^{53}$ Hurd, 'Theories and tests of international authority' ( $\ldots$ _ $) 25$

${ }^{54}$ Thomas Risse, ‘"Let's argue!'’: communicative action in world politics' (2000) 54 International Organization 1-39
} 
give publicly as one operational indicator of authority. ${ }^{55}$ Indeed, a related concern for rhetorical action is also central in his work on how states fight over the authority over the UN Security Council in order to increase their power by being associated with its symbols, where authority is regarded as a strategic asset involved in a political game of legitimation and delegitimation. ${ }^{56}$

\section{David Lake - authority as a social contract}

David Lake explores authority and the existence of hierarchy in relations among states from a rationalist social contract framework, distinct from Hurd's more constructivist account. ${ }^{57}$ In contrast to the traditional formalistic view, Lake sees authority as "a social contract in which a governor provides a political order of value to a community in exchange for compliance by the governed with the rules necessary to produce that order." ${ }^{, 58}$ The contractarian conception of authority allows Lake to reconceive global governance as the set of actors that wield authority over some limited community across national borders. This definition includes states exercising authority over other states (hierarchy), international organizations exercising authority over their members (supranationalism), and even non-governmental organizations and corporations that exert authority over transnational communities (private authority), ${ }^{59}$ but rules out various kinds of non-authoritative relationships in which agents may also be entangled (symmetrical cooperation, conflict, etc). Moreover, the definition need not imply that global governance aims at and (ideally) succeeds in resolving common problems in a Pareto-improving way. That may sometimes be the case, but not necessarily:

"Authority can also be used to benefit a governor or her supporters at the expense of others in the relevant community. Authority is always wielded by someone for some purpose:

\footnotetext{
${ }^{55}$ Hurd, 'Theories and tests of international authority' (n__) $34 \mathrm{f}$

${ }^{56}$ Hurd, 'Myths of Membership' (n __); Hurd, After anarchy (

${ }^{57}$ David A. Lake, Hierarchy in international relations (Cornell University Press 2009)

${ }^{58}$ David A. Lake, 'Rightful Rules: Authority, Order, and the Foundations of Global Governance' (2010) 54 International Studies Quarterly 587, 589

${ }^{59}$ Ibid. 590
} 
sometimes it is used to increase the welfare of everyone in a community, sometimes to distribute from the governed to the governor (and her supporters), and sometimes for both ends simultaneously."60

Like most theorists of authority, Lake defines authority in terms of legitimacy as rightful rule. ${ }^{61} \mathrm{He}$ here draws on the classical conception of legitimacy as a tripartite right of the ruler to rule, to be obeyed (i.e., the authority's right to rule corresponds to the subject's duty to obey) and to coerce noncompliance. Notably, there is a degree of freedom in this conception of authority: In a relationship of authority, the subjects decide whether or not to comply with the governor's commands, but their obligation to comply corresponds to the governor's right to discipline or punish their noncompliance. Thus, authority is an interactive relation of power between two agents, where "A commands B, and B responds at least in part from obligation, but B still does something he would otherwise not."62

Lake models the relation between authority, coercion and self-interest differently than Hurd. Certainly, authority is conceptually distinct from coercion, because unlike coercion, authority involves a duty to comply. However, the two are closely related and often difficult to distinguish in practice, as coercion constitutes a necessary component of authority. Since subjects may sometimes have incentives to disobey, the authority must have the capacity for coercion in order to enforce its decisions and to deter defection by other subjects. Thus, in general, political authority and coercion are complementary, but in some cases they may rather be supplementary, such as when a ruler increases its use of coercion in order to withstand challenges to its authority. ${ }^{63}$ For Lake, then, the fear of punishment (coercion) is not an indication of the absence of authority/legitimacy; rather, a potential for coercion is always part of the calculus. Indeed, on the constitutivist account that Patrick Smith develops in his contribution to this issue, a capacity to decisively adjudicate disputes between subjects

\footnotetext{
${ }^{60}$ Ibid. 591

${ }^{61}$ Ibid.

${ }^{62}$ Ibid. 592

${ }^{63}$ Lake, 'Escape from the State of Nature' (
} 
and enforce those adjudications reliably serves as an important requirement of legitimacy. In the absence of coercive political authority, individual rights could never be safeguarded.

Furthermore, legitimacy does not preclude self-interest: Since the dominant state provides a social order, it is often in the interest of the subordinate state to comply with its demands. But compliance with authority is observationally equivalent both to more symmetrical cooperation and to coercion. Lake suggests looking for authority in symbolic obeisance, i.e., costly actions subordinates take in order to signal their assent to authority, such as following the dominant state into distant wars in which they have no direct stakes. ${ }^{64}$

While the Razian conception of authority presupposes a dyadic relation between ruler and subject, Lake suggests that authority relationships are triadic, as they crucially rely on the acceptance of a wider community, which confers on the ruler the right to rule and, specifically, the right to punish those who fail to comply. In this issue, Venzke similarly asserts that authority emerges when a broader social belief exists that a subject should do something because another agent said so, and Hentrei conceives of complementarity as built on both individual freedom and collective self-determination. On Lake's account, this triadic constellation helps resolve the "apparent contradiction that, from the perspective of collectivity, compliance with legitimate authority is voluntary, but from the standpoint of any particular individual, compliance is mandatory." ${ }^{65}$ Finally, authority, on Lake's view, is institutionalized "as social interests the governed invest in assets specific to that authority and the rules it produces." Institutionalization is not an inherent property of authority, but rather follows from the social interests parties vest in any particular social contract. "As a negotiated compact, authority must benefit on average the members of the relevant society." ${ }^{66}$ Of course, subjects may disagree about whether a particular social arrangement benefits them compared to some hypothetical second-best alternative. This is why debates on authority are contentious - people may disagree about what the appropriate counterfactuals are. However, authority by itself creates distributional effects. Those who

${ }^{64}$ David A. Lake, 'Relational Authority and Legitimacy in International Relations' (2009) 53 American Behavioral Scientist 331, 347

${ }^{65}$ Lake, 'Rightful Rules' (n__) 592

${ }^{66}$ Ibid. 593 
benefit from authority thus have interests to preserve it and defend it, but "even when everyone in society benefits from having a social order in general, some always benefit more than others. ${ }^{, 67}$

Lake's conception of authority is conceptually clarifying and generates a range of empirical expectations about hierarchical relations between states. However, it may seem less applicable to authority as exercised by international institutions, since he forges a close link between authority and coercive capacity, something which - as we pointed to earlier - global governance institutions usually neither have nor aspire for (cf. Smith, this issue) ${ }^{68}$ In this sense, Lake operates within a more traditional realist framework, where institutions reflect hierarchical relationships between a dominant state and its subordinates. While the conventional legal-formal conception of authority may fail to account for how authority emerges in the absence of a prior lawful institution, Lake's approach may seem correspondingly unable to explain the emergence of international institutions that take on a life of their own, for instance by being able to sustain their authority even as the underlying relations of hierarchy shift, or to acquire authority over new issues beyond the original mandate of the states that created them. ${ }^{69}$ Contractarian notions of authority entail a classic bootstrapping problem which Venzke addresses in his piece: How could authority rest on voluntary agreement if it binds subjects even against their will?

While Lake provides a positive theory of authority and hierarchy aimed at explaining certain patterns of behaviour in world politics, some normative implication may be teased out of his argument. It draws heavily on social contract theory and sees authority as originating in the interests of the subjects in exchanging some of their freedom for social order. Hence, "obligations flow not from the commands of the ruler, but from the consent of the ruled". ${ }^{70}$ Thus, consent provides the essential notion of legitimacy for this theory, which may resonate with the voluntarist, delegationist view of international legitimacy, with all its well-rehearsed theoretical weaknesses. Similarly, one might find

\footnotetext{
${ }^{67}$ Lake, 'Rightful Rules' (

${ }^{68}$ Buchanan, 'The legitimacy of international law' (n _ $)$

${ }^{69}$ Clifford James Carrubba, 'A Model of the Endogenous Development of Judicial Institutions in Federal and International Systems' (2009) 71 The Journal of Politics 55

${ }^{70}$ Lake, 'Escape from the State of Nature' (
} 
this consent-based notion of legitimacy problematic to the extent that it collapses legitimacy and selfinterest as reasons for action. As Buchanan \& Keohane argue, "it makes sense to ask whether an institution that promotes one's interests is legitimate". ${ }^{71}$

\section{Zürn et al - Contesting the legitimacy of authority}

Notwithstanding their differences, Raz, Hurd and Lake share the notion of political authority as legitimated power. By contrast, Michael Zürn, Martin Binder and Matthias Ecker-Ehrhardt disentangle the popular conflation of authority and legitimacy (similar to Bogdandy et al), in order to theorize the responses the international institutions elicit in the various agents subject to their exercise of authority. ${ }^{72}$ Zürn et al take as their starting point the ways in which international institutions have developed procedures that contradict the basic norms of Westphalian sovereignty. In some instances, rules and decisions by international institutions compel national governments to take actions they have not consented to, while in other cases, they affect individuals directly. Such phenomena, Zürn et al argue, indicate that international institutions exercise public authority: An institution has authority when the actors its policies address recognize that it can make competent judgments and binding decisions: "International institutions exercise authority in that they successfully claim the right to perform regulatory functions like the formulation of rules and rule monitoring or enforcement." ${ }^{, 73}$ As Enroth notes in his contribution to this issue, while this conception seems to equivocate between de facto and de jure authority, focusing on the behavioural instantiation of the right to rule may be useful for empirical study.

What happens when international institutions take on regulative functions usually performed by states? Zürn's et al central claim is that such instances of international institutional authority require

\footnotetext{
${ }^{71}$ Allen Buchanan and Robert O. Keohane, 'The Legitimacy of Global Governance Institutions' (2006) 20 Ethics \& International Affairs 405, 409

${ }^{72}$ Michael Zürn, Martin Binder, and Matthias Ecker-Ehrhardt, 'International authority and its politicization' (2012) 4 International Theory 69-106; cf. Michael Zürn and Matthew Stephen, 'The View of Old and New Powers on the Legitimacy of International Institutions' (2010) 30 Politics 91101

${ }^{73}$ Zürn, Binder, and Ecker-Ehrhardt, 'International authority and its politicization' (n__ $) 70$
} 
legitimation and leads to politicization, which they define as "growing public awareness of competing political preferences regarding institutions' policies or procedures." 74 Politicization occurs to the degree that various social groups either challenge and resist international institutions or increasingly use them in order to further their own purposes. Either way, the exercise of authority raises public awareness: "The more political authority international institutions exercise ..., the more they attract public attention and demands." ${ }^{75}$ However, authority does not automatically generate politicization there must be specific opportunity structures in place.

Many conceptions of authority link it so closely to legitimacy as to make 'legitimate authority' tautological, and the two notions virtually indistinguishable. However, embedding legitimacy in the definition of authority may be both analytically and empirically problematic, especially if you want to theorize how international authority relates to resistance, mobilization and contestation. Zürn et al point to two counterintuitive implications with this 'folk theorem of authority'. First, if legitimacy and authority are two sides of a coin, then the more authority an institution has, the more legitimate it must be. This runs counter to experience: Sometimes institutions acquire authority over new issues without necessarily being seen as more legitimate by all actors. Second, the folk theorem seems to deny the existence of illegitimate authority - which might seem troubling for both normative and conceptual reasons, as we mentioned earlier.

Instead, Zürn et al suggest that 'legitimate authority' can be unpacked as involving two ways in which a political institution can be acknowledged or recognized as a ruler by the relevant social agents. First, a political institution has authority when the relevant social agents recognize that it has the capacity to make competent judgments or binding decisions, as necessary for obtaining certain common goods. This is similar to Lake's social contract conception, and it also implies hierarchy; it is also close to the Razian explication of political authority, which Raz assumes to fulfill the service conception if authority was consented to. Second, a political institution may be legitimate in its exercise of authority in so far as the rules and judgments it produces are consistent with normative

\footnotetext{
${ }^{74}$ Zürn, Binder, and Ecker-Ehrhardt, 'International authority and its politicization' ( ${ }^{75}$ Ibid. 71
} 
beliefs about the common good and procedural fairness shared within a community. Put differently, one may think of authority as a form of power that can be the object of legitimation. To conceptually separate authority and legitimacy has certain analytical advantages. For instance, an authority may persist and yet face charges of legitimacy deficits - i.e., the relevant community may recognize that an institution has the competence to regulate a certain issue-area, yet increasingly regard its decisionmaking procedures and decisions as unfair or unrightful. Empirically, Zürn et al expect that an authority's degree of legitimacy affects the level and type of politicization it faces. ${ }^{76}$

Zürn et al distinguish between epistemic and political authority as two types of authority that can be exercised by international institutions. Epistemic authority, on their view, is usually undemanding in terms of legitimation, and authority and legitimacy go hand in hand. Political authority, by contrast, requires more demanding legitimation because it involves the capacity to issue rules and decisions that the community recognizes as collectively binding, and which sometimes disadvantage some community members relative to others. This distinction raises the question about other plausible types of authority, their corresponding need for legitimation, and the relation between different notions of authority. For instance, the authority exercised by international judicial institutions is not confined just to its epistemic dimensions, i.e., the legal expertise of the court's judges, yet usually are not collectively binding on the members of a community. Moreover, in other cases epistemic authority may translate into political authority, i.e., expertise in a certain area is the basis of an authority's claim to issue collectively binding rules (e.g., regulatory agencies in various areas, such as health, telecommunications, environment, etc.). Such instances may turn out to be just as demanding in terms of legitimation and to provoke similar politicization.

Exploring these matters, Onderco, Hola \& Ruiter (this issue) draw on Zürn et al to assess the independence of international criminal tribunals. While the authority per se of these institutions is well established, existing literatures assume them to be highly politicized in their exercise of that authority. Yet Onderco, Hola \& Ruiter's findings show that judges on the ICTY actually make their sentencing decisions largely detached from political bias, which may be due either to their institutional set-up, or

\footnotetext{
${ }^{76}$ Ibid. 85
} 
the fact that state preferences on the rulings are relatively unclear, compared to other types of international judicial bodies.

\section{Conclusion}

Just as claims to authority by transnational actors may provoke reactions, the concept of authority remains highly contested in the study of international affairs. This introduction has served to highlight some of these controversies and conversations. Yet, for all their differences, the contrasting conceptions of authority that we have surveyed here and the contributions to this issue demonstrate that there is also common ground. The turn to authority, and the disagreements about how to conceive it, have extended the reach of the concept of authority as such (cf. Enroth) but it has also helped spawn novel empirical hypotheses of phenomena previously invisible to researchers, and raised previously neglected or even unthinkable normative questions on the agenda of researchers, and perhaps of society at large too. In that sense, and as evidenced by the contributions to this special issue, the turn to authority beyond states represents a productive and innovative research programme. 